\title{
The Use of Peer-Correction to Improve Student Writing Skill at STMIK Stikom Indonesia
}

\author{
Komang Trisnadewi \\ UHN I Gusti Bagus Sugriwa Denpasar \\ e-mail: kmgtrisna@yahoo.com
}

\begin{abstract}
In the process of producing a writing in English, students certainly experience difficulties since English is a foreign language as experienced by students of STMIK STIKOM Indonesia. The preliminary observation showed that students have problem in all components of writing and tends to repeat the same mistakes. To overcome these problems, peer-correction techniques are implemented. This study was conducted to improve students' writing skill using peer-correction, find the most affected component of writing and show students' responses. There are three steps in this study including pretest, implementation of peer-correction and post-test. Pre-test was conducted at the beggining of the meeting with the aim of knowing the initial ability of students' writing. The implementation of peer-correction was conducted in two cycles which each cycle including planning, implementation of action, observation and final reflection. Post test was conducted in each cycle to determine the ability of students' writing after implementing peer-correction techniques. The result showed that the implementation of peer-correction techniques was able to improve students' writing skill in terms of content, organization, vocabulary, language and mechanics in which content is the most affected. Moreover, students showed positive response toward the implementation of peercorrection.
\end{abstract}

Keywords: writing, peer-correction, writing component

\section{Introduction}

Writing is one of four skills that a person must have when learning a language, including English. Writing skill is one of the productive and expressive language skills that are used to communicate indirectly with other people (Tarigan, 2015). Writing skill is the ability to express ideas, opinions and feelings to other people through written language (Abbas, 2006) . It can be said that writing is the ability to express ideas which aims to communicate with other people.

In producing a writing, there are several components that must be considered. Writing does not only make one sentence or just a few unrelated things, but produces an orderly series of things, which relate to one another, and in a certain style (Byrne, 1988). As stated by Gie, there are four elements that must be considered in writing. The first is an idea which can be an opinion, experience, or knowledge that is in a person's mind. The second is speech, which is the expression of ideas so that the reader can understand them. The third is order, namely the orderly arrangement and arrangement of ideas by conveying various principles, technical rules, to planning, framework, and steps. The 
fourth is a vehicle or also called a tool which mainly concerns about vocabulary, grammar, and rhetoric (Nurudin, 2007).

Writing is one of the language skills taught to students at University. Writing is very beneficial for us because through it, we can train our thinking skills and develop ideas and to further clarify our intentions and ideas to readers. Percy explains some of the benefits of writing, namely as a means of selfexpression, a means of understanding, helping to develop personal satisfaction, pride, feelings of self-worth, increasing awareness and absorption of the environment, passionate involvement, not resigned acceptance, and develop an understanding and ability to use language (Nurudin, 2007).

In the process of producing a writing in English, students certainly experience difficulties since English is a foreign language for them as experienced by students of class AA, semester III STMIK STIKOM Indonesia. Students have ideas to write in their mind, but sometimes it's difficult to put them into sentences. If it is successful in expressing it in the form of a sentence, the sentences used also have a lot of mistakes in content, organization, vocabulary, language use and mechanics. Unfortunately, the grammatical errors are repeated in the next sentence. This can be seen in their writing when asked to make a descriptive paragrpah. From the observations by the researcher who was also a lecturer in the class, there were various grammar mistakes found in students. Moreover, students were not confidence with their writing. They feel more comfortable when doing discussion with their friends instead of doing individually.

Grammar has an important role in writing. Writing with chaotic grammar can cause misunderstanding from the reader and the reader does not tend to continue reading the writing until it's finished. Writing with many language errors is a futile activity because the writing will not be read by people. Conversely, essays with minimal language errors allow the reader to fully understand the content (Hendrickson, 1981).

As a writer, before publishing the results of our writing, it is hoped that we can correct our own writing to minimize existing errors. From the interview results, it was found that the student's writing had never been corrected by the previous lecturer. The lecturer explained the grammar used and the stages in writing, but did not provide clear corrections to the mistakes made. Therefore, students repeat the same mistakes and consider their writing to be correct. Students do not clearly know the mistakes and students are not directly involved in the correction process. From the first impression when teaching, it appears that students are less motivated in learning and less confident in conveying their opinions individually, but when working in groups, students feel more confident. 
Correction is important for students to increase their awareness of language use (Moini, 2009). The purpose of the correction itself is to facilitate students to learn new language items correctly. It is evident from the literature that using error correction as a means of fostering writing development is a benignant way to improve the writing proficiency of the language learners (EKİNCI, 2020). Therefore, students need correction when learning a language (Amara, 2015). There are three types of correction, namely selfcorrection, peer-correction, and teacher-correction. People prefer to correct their own mistakes rather than be corrected by others. They also added that self-correction is easier to remember because it sticks in their heads. Furthermore, with peercorrection, whether the person making the mistake or the person correcting, both are involved in listening and thinking about the language. Teacher-correction is where the lecturer or teacher takes the role of giving the correct answer. The three techniques mentioned have their respective advantages and disadvantages (Edge, 1997).

Feedback is useful when students have less knowledge, especially mistakes in using language (Khansir \& Pakdel, 2018) . If writing papers mostly marked without mentioning students' errors, so the students will be able not to identify what are their error (Hussein, 2020). Correction of errors is not easy and should be instructed by the teacher. Correction of errors is one way to develop competency in learning languages as both a second language and a foreign language. Students who learn English as a foreign language have positive behavior towards reciprocal correction of lecturers (Kahraman \& Yalvaç, 2015). Most students expect their teachers to correct and correct the mistakes they make and believe that error correction is the responsibility of a teacher (Lee, 2005). However, based on the results of research conducted by Ganji, it is stated that the teachercorrection method only consumes energy and time (Ganji, 2009).

Moreover, Ganji said that the other two methods, self-correction and peer-correction are very effective in improving writing skills. The use of self-correction is able to identify problems faced and motivate them to produce better writing (Rana \& Perveen, 2012). Peer-correction technique can improve the quality of the results and the scientific writing process of learning. However, the application of this technique must be adjusted to the character of the students, their background knowledge and the number of students (Ulfah, Maria; Fuady, Amir; Wardani, 2013). Students are extremely interested to peercorrection activities (Rahmasari \& Sidabalok, 2020). Students said that peer correction motivate them when their friends' work are better than them (Tsuroyya, 2020). Peer feedback reduces the students' writing anxiety levels, 'the students' physical and cognitive reactions to writing anxiety changed in a positive 
way by the end of the study, and it encouraged students to use English to write compositions (YastÕbaúa, G. C., YastÕbaúa, 2015). Some research subjects believed that peer feedback helped writing learning (Lin \& Chien, 2009).

Based on the preliminary observation at STMIK STIKOM Indonesia, this study aims to improve students' writing skills. This study uses peer correction to improve students' writing skills based on the literature review above and adjusts to the situation of students in the research place. Different from previous research, in addition to improving students' writing skills, this study also aims to see which components were most influenced by the implementation of peer correction. Besides, students' responses are also discussed.

\section{Method}

A classroom action research is used in this study. There are four steps in each cycles of classroom action research including planning, (2) implementing, observing, and (4) evaluating or reflecting (Arikunto, 2010). The research subjects were 30 students of class AA (3rd semester) of STMIK STIKOM Indonesia which is located at Jalan Tukad Pakerisan No. 97, Panjer, Denpasar. The data was taken by doing observation, interview, giving a test and questionnaire. Observation, interview and questionnaire are used to find the students' responses of peer-correction implementation. Whereas test is used to know the ability of students in writing. The research data is in the form of students' writing, result of interview, observations, and questionnaires.

The steps taken in this study are as follows.

\section{Pre-action}

At this stage the researcher observes students in a learning process and observes the results of student writing by giving a pre-test. Interviews were also conducted to obtain supporting data so that research problems could be formulated for further purposes of research.

\section{Planning}

This stage contains plans that will be carried out to overcome the problems and constraints that have been formulated in the previous stage.

\section{Implementation of actions}

This stage describes the actions taken by researchers during the learning process in order to overcome problems faced by students. Peer-correction is implemented in improving student's writing skill.

\section{Observations}

This stage is carried out by observing the results of the actions that have been taken.

\section{Final reflection}

At this stage, all data obtained from the results of the action are then 
analyzed, observed, and reviewed by the author.

\section{Post-test}

At this stage, students were given a post-test.

The data in this study are in the form of student writing, the results of observations and interviews as well as a questionnaire after being analyzed then presented in quantitative and qualitative forms.
In assessing students' writings, ESL Composition is used. According to Jacob, writing skills can be assessed by a Benchmark Reference Assessment (PAP) which is based on the ESL Composition Profile with the following assessment format (Sutarma, I Gusti Putu; Adnyana, 2014).

\section{Table 1. Reference Assessment Format (PAP) based on the ESL Composition}

Profile

\begin{tabular}{|c|c|c|}
\hline Aspect & Level & Criteria \\
\hline Content & $\begin{array}{l}21-18 \\
16-13\end{array}$ & $\begin{array}{l}\text { EXCELLENT TO VERY GOOD: knowledgeable, substantive, thorough } \\
\text { development of thesis, } \\
\text { relevant to assigned topic. } \\
\text { GOOD TO AVERAGE: some knowledge of the subject, adequate range, limited } \\
\text { development } \\
\text { of thesis lacks of detail, mostly relevant the topic. } \\
\text { FAIR TO POOR: limited knowledge, little substances, in adequate development } \\
\text { of thesis. } \\
\text { VERY POOR: does not show knowledge of subject, non-substantive, not } \\
\text { pertinent. }\end{array}$ \\
\hline Organization & $\begin{array}{l}17-14 \\
13-10 \\
9-7\end{array}$ & $\begin{array}{l}\text { EXCELLENT TO VERY GOOD: fluent expression, ideas clearly stated/ } \\
\text { supported, succinct, } \\
\text { well organized, logical sequencing, cohesive. } \\
\text { GOOD TO AVERAGE: somewhat choppy, loosely organized but main ideas } \\
\text { stand out, limited support, logical but incomplete sequencing. } \\
\text { FAIR TO POOR: non-fluent, ideas confused or disconnected lacks of logical } \\
\text { sequencing and development. } \\
\text { VERY POOR: does not communicate, no organization, or not enough to } \\
\text { evaluate }\end{array}$ \\
\hline Vocabulary & $20-18$ & $\begin{array}{l}\text { EXCELLENT TO VERY GOOD: sophisticated range, effective word/ idiom } \\
\text { choice and usage, } \\
\text { word form mastery, appropriate register. } \\
\text { GOOD TO AVERAGE: adequate range, occasional errors of word/ idiom form, } \\
\text { choice, usage } \\
\text { but meaning not obscured. } \\
\text { FAIR TO POOR: limited range, frequent errors of word/ idiom form, choice, } \\
\text { usage, meaning } \\
\text { confused or obscured } \\
\text { VERY POOR: essentially translation, little knowledge of English vocabulary, } \\
\text { idioms, word } \\
\text { form, OR not enough to evaluate. }\end{array}$ \\
\hline & $25-22$ & $\begin{array}{l}\text { EXCELLENT TO VERY GOOD: effective complex construction, few errors } \\
\text { agreement, tense, } \\
\text { number, word order/ function, articles, pronouns, preposition. } \\
\text { GOOD TO AVERAGE: effective but simple construction, minor problems in } \\
\text { complex } \\
\text { construction, several errors of agreement, tense, number, word order/ function, }\end{array}$ \\
\hline
\end{tabular}




\begin{tabular}{|c|c|l|}
\hline \multirow{2}{*}{$\begin{array}{l}\text { Language } \\
\text { Use }\end{array}$} & $\begin{array}{l}\text { articles, } \\
\text { pronouns, prepositions but meaning seldom obscured. } \\
\text { FAIR TO POOR: major problems in simple/complex construction, frequent } \\
\text { errors of negation, } \\
\text { agreement, tense, number, word order/function, articles, pronouns, prepositions } \\
\text { and/or } \\
\text { fragments, run-ons, deletions, meaning confused or obscured. } \\
\text { VERY POOR: virtually no mastery of sentence construction rules, dominated by } \\
\text { errors, does } \\
\text { not communicate, OR not enough to evaluate }\end{array}$ \\
\hline $50-5$ & $\begin{array}{l}\text { EXCELLENT TO VERY GOOD: demonstrates mastery of conventions, few } \\
\text { errors of spelling, } \\
\text { punctuation, capitalization, paragraphing. } \\
\text { GOOD TO AVERAGE: occasional errors of spelling, punctuation, paragraphing } \\
\text { but meaning } \\
\text { not obscured } \\
\text { FAIR TO POOR: frequent errors of spelling, punctuation, capitalization, } \\
\text { paragraphing, poor } \\
\text { handwriting, meaning confused or obscured. } \\
\text { VERY POOR: mastery of conventions, dominated by errors of spelling, } \\
\text { punctuation, } \\
\text { capitalization, paragraphing, handwriting illegible, OR not enough to evaluate. }\end{array}$ \\
\hline 2 & 5
\end{tabular}

Table 2. Classification of student's writing score

\begin{tabular}{|c|c|}
\hline $85-100$ & Very good \\
\hline $72-84$ & Good \\
\hline $51-71$ & Fair \\
\hline $34-50$ & Poor \\
\hline
\end{tabular}

\section{Results and Discussion Pre-action}

There are several activities carried out at this stage. The first activity is the lecturer asked students to write a descriptive text with free topics and is given 40 minutes. Furthermore, the lecturer assesses the student's writing by using the Reference Assessment Format (PAP) which is based on the
ESL Composition Profile. The third activity is to interview students regarding difficulties faced while writing and also ask about their experiences related to corrections to their writing. Furthermore, in the fourth activity, possible causes of student problems were identified. The results of the assessment are described in the following table.

Table 3. Pre-test

\begin{tabular}{|c|c|c|c|}
\hline Student & Pre-test & Student & Pre-test \\
\hline 1 & 53 & 16 & 52 \\
\hline 2 & 48 & 17 & 54 \\
\hline 3 & 48 & 18 & 48 \\
\hline 4 & 52 & 19 & 52 \\
\hline 5 & 48 & 20 & 53 \\
\hline 6 & 55 & 21 & 48 \\
\hline
\end{tabular}




\begin{tabular}{|c|c|c|c|}
\hline 7 & 48 & 22 & 48 \\
\hline 8 & 52 & 23 & 52 \\
\hline 9 & 52 & 24 & 51 \\
\hline 10 & 51 & 25 & 51 \\
\hline 11 & 52 & 26 & 47 \\
\hline 12 & 50 & 27 & 49 \\
\hline 13 & 54 & 28 & 50 \\
\hline 14 & 51 & 29 & 45 \\
\hline 15 & 52 & 30 & 45 \\
\hline
\end{tabular}

Based on the table above, it is known that the mean score is 50,3 and is in the poor category.

In more detail, the student writing component is described as follows.

\section{Contents}

The content of student writing tends to be unclear, less detailed, less translucent and still limited. There are even some student writings that don't hit the mark and don't match the contents. There are student writings which only consist of 2 sentences.

\section{Organization}

The writing produced in the sequence is still less logical, less orderly and tidy, and the cohesion is not high enough. Sentences that should be in second place, but are placed first like the following example.

3. Vocabulary

The words that are used tend to be repetitive and limited, they do not master word formation, and the choice of words is not quite right.

\section{Language use}

Students lack grammar skills. There are still many of them who find it difficult when making simple sentences.

5. Mechanics
Lack of mastery of writing rules and there are some of them whose writing is difficult to read.

\section{Peer-Correction Implementation Cycle I}

After the pre-action stage, it is known that the cause of the students' lack of writing ability is no feedback on student writing and the lack of student involvement in the correction activity. Therefore, this study uses peer-correction techniques in an effort to overcome these problems with the following steps.

1) Determining the writing theme At this stage, the lecturer determines the theme of the writing that must be written by students. The theme is adjusted to the learning syllabus used in the Indonesian STMIK STIKOM course of English III for the third semester.

2) Setting writing goals.

The students are explained about the objectives of learning to write so that students have an understanding of it. The lecturer also explains the stages of activities that will be carried out in the implementation of this technique.

3) Pre-writing stage

At this stage, the lecturer provides an explanation through a presentation 
on learning to write. Previously, students had received the basic theory of writing in English I and II courses. The lecturer invited students to ask questions and answers related to the development of writing ideas. One way is to use WH questions. Students are asked to make questions related to the theme of the writing that must be made. Lecturers guide this activity and help if there are students who have difficulties. At this stage, proper grammar usage procedures and examples are also explained.

4) Writing a draft

After the questions were formulated in the previous stage, then at this stage the lecturer asked students to write down the answers to the questions that had been formulated into paragraphs. The lecturer gives directions to students to put their ideas into sentences without being afraid to make mistakes. The lecturer gives a certain amount of time for students to complete the draft.

5) Doing correction (peer-correction)

At this stage, the lecturer tells students to correct a friend's writing based on the material that has been previously given. The lecturer explains the implementation of peercorrection and its purpose and benefits. Students are asked to exchange writings with their friends. Furthermore, each student is asked to correct his friend's writing by providing notes on the writing. The correction including content, organization, vocabulary, language use and mechanics.

6) Write the final result of the writing. At this stage students are asked to rewrite their writing by considering the results of their friends' corrections.

After implementing peer-correction, students asked to make a writing with same topic and they are given 40 minutes to do it. Then, the students' writing results are collected for further correction. The results of students' writing after being assessed using the Reference Assessment Format (PAP) based on the ESL Composition Profile are shown as follows.

Table 4. Post-Test I

\begin{tabular}{|c|c|c|c|}
\hline Student & Post-test I & Student & Post test I \\
\hline 1 & 73 & 16 & 67 \\
\hline 2 & 71 & 17 & 68 \\
\hline 3 & 65 & 18 & 67 \\
\hline 4 & 67 & 19 & 71 \\
\hline 5 & 67 & 20 & 67 \\
\hline 6 & 73 & 21 & 67 \\
\hline 7 & 65 & 22 & 65 \\
\hline 8 & 68 & 23 & 71 \\
\hline 9 & 69 & 24 & 71 \\
\hline 10 & 71 & 25 & 72 \\
\hline
\end{tabular}




\begin{tabular}{|l|l|l|l|}
\hline 11 & 70 & 26 & 67 \\
\hline 12 & 69 & 27 & 71 \\
\hline 13 & 69 & 28 & 70 \\
\hline 14 & 67 & 29 & 71 \\
\hline 15 & 67 & 30 & 70 \\
\hline
\end{tabular}

Based on the table above, it is known that the mean score is 68.8 and it is in fair category.

The explanation for the student writing component is as follows.

\section{Contents}

The contents of the students' writings have begun to become clear, some are detailed although the rest are not yet elaborated.

\section{Organization}

The writing that is produced in the sequence has started to be organized and has good cohesion.

3. Vocabulary

The repetition of vocabulary has started to decrease, although there are still some writings that use repeated words so that they are a bit monotonous. Some writings still use inappropriate vocabulary.

4. Language use
Simple sentences made by students have good grammar, but errors can still be seen in more complex sentences.

5. Mechanics

Student writing is easy to read and much tidier than ever.

\section{Cycle II}

After seeing the results in cycle I, it is very necessary to carry out cycle II to involve the changes that occur in student writing. The implementation steps are the same as during the implementation of cycle I, but the lecturer emphasizes more on the importance of applying peercorrection which is not only to help a friend's writing, but also as a way to practice writing skills. The results of the $2^{\text {nd }}$ post-test can be seen in the table below. 
Table 5. Post-test II

\begin{tabular}{|c|c|c|c|}
\hline Student & Post-test II & Student & Post-test II \\
\hline 1 & 82 & 16 & 83 \\
\hline 2 & 81 & 17 & 83 \\
\hline 3 & 80 & 18 & 86 \\
\hline 4 & 81 & 19 & 88 \\
\hline 5 & 83 & 20 & 87 \\
\hline 6 & 86 & 21 & 84 \\
\hline 7 & 85 & 22 & 84 \\
\hline 8 & 86 & 23 & 86 \\
\hline 9 & 85 & 24 & 86 \\
\hline 10 & 84 & 25 & 86 \\
\hline 11 & 84 & 26 & 83 \\
\hline 12 & 86 & 27 & 83 \\
\hline 13 & 83 & 28 & 82 \\
\hline 14 & 82 & 29 & 82 \\
\hline 15 & 82 & 30 & 84 \\
\hline
\end{tabular}

Based on the table above, it is known that mean score is 83.9 and it is good category.

The explanation for the student writing component is as follows.

\section{Contents}

The contents of the student writings are clear, already detailed. The development of topics made by students is very good. Almost the same as the scores during the cycle, the contents of the students' writings were detailed and elaborated. Students are able to develop ideas from their thoughts.

\section{Organization}

The resulting writing has an orderly sequence and has a better cohesion than cycle I. The sequence of sentences in student writing is well structured.

3. Vocabulary

The vocabulary used by students began to vary. It was seen that students avoided repetition of words and were very careful in choosing the right vocabulary. Student vocabulary increases. Students are getting better at choosing the right vocabulary to use in their sentences.

\section{Language}

There are still errors in grammar, but the number is small and those mistakes are not mistakes occurred in cycle I. This means that students do not repeat the same mistakes. Grammar errors still appear in the post-test. Most likely the mistake they make is the lack of accuracy when writing because with the same grammar pattern, the error only appears in the first sentence while the next sentence does not.

5. Mechanics

Students' writings are easy to read. Students really pay attention to the beauty of writing, in addition to the content of the writing. Their writing is neat and there are no scribbles. 


\section{Students' Responses}

The result of questionnaire showed that 28 students strongly agreed that the peer-correction technique really helped them in improving their writing skill and 2 others answered agreed. Regarding to the benefits, all students said they had benefited from the peercorrection implementation. Some said that it is fun to check someone's writing and fell so motivated to do better than others. They are not afraid anymore to convey ideas. Some students also said they felt more confident and wanted to do it again.

The challenges or obstacles faced by students during the implementation of peer-correction are when facing vocabulary that they do not know the meaning of, grammar that they do not actually understand, words that are not clearly written, and limited time of doing correction.

Students suggest to do peercorrection frequently so they will be more familiar with English writing and more confident in correcting both their own writing and their friends. In addition, the correction time should be given longer.

\section{Conclusion}

Based on the explanation above, it can be concluded that peercorrection is proven to improve the writing skills of class AA $\left(3^{\text {rd }}\right.$ Semester) of STMIK STIKOM students. It can be used as a correction technique to improve writing skills. All component of writing including contents, organization, vocabulary, language use and mechanics are improved. Content is the component which affected the most. Moreover, students showed positive respond toward the implementation of peer-correction. They felt more confidence in writing. However, preparation is important before doing peer-correction. It is ensured that students must have sufficient knowledge of the topic of writing.

There are some suggestions for further research. Other researches can observe other aspects that are influenced by the implementation of peer-correction. Besides, it can be implemented in improving others language skills. 


\section{References}

Abbas, S. (2006). Pembelajaran Bahasa Indonesia Yang Efektif Di SD. Departemen Pendidikan Nasional Direktorat Jendral Pendidikan Tinggi.

Amara, N. (2015). Errors Correction in Foreign Language Teaching. The Online Journal of New Horizons in Education, 5(3), 58-68.

Arikunto, S. (2010). Prosedur Penelitian Suatu Pendekatan Praktik. Rineka Cipta.

Byrne, D. (1988). Teaching Writing Skills. Longman.

Edge, J. (1997). Mistakes and Correction. Longman.

EKİNCI, M. E.-E. (2020). USING ERROR CORRECTION CODES TO IMPROVE WRITING SUCCESS OF EFL LEARNERS. International Journal of Language Academy, 8(4), 282-293. https://doi.org/10.29228/ijla.4532 4

Ganji, M. (2009). Teacher-correction , Peer-correction and Selfcorrection: Their Impacts on Iranian Students' IELTS Essay Writing Performance. The Journal of Asia TEFL, 6(1), 117-139.

Hendrickson, J. (1981). Error Analysis and Error Correction in Language Teaching. Seameo Regional Language Centre.

Hussein, S. M. (2020). The Correlation between Error Correction and Grammar Accuracy in Second Language Writing. International Journal of Psychosocial Rehabilitation, 24(5), 2980-2990. https://doi.org/10.37200/ijpr/v24i 5/pr202003
Kahraman, A., \& Yalvaç, F. (2015). EFL Turkish University Students' Preferences about Teacher Feedback and its Importance. Procedia - Social and Behavioral Sciences, 199, 73-80. https://doi.org/10.1016/j.sbspro.2 015.07.489

Khansir, A. A., \& Pakdel, F. (2018). Place of Error Correction in English Language Teaching. Educational Process: International Journal, 7(3), 189-199. https://doi.org/10.22521/edupij.2 018.73 .3

Lee, I. (2005). Error COrrection in the L2 Writing Classroom: What DO Students Think? TESL Canada Journal, 22(2), 1-16.

Lin, G. H. C., \& Chien, P. S. C. (2009). An Investigation into Effectiveness of Peer Feedback. Online Submission, 3(1983), 79-87. Moini, M. R. (2009). The impact of EFL teachers' cognition on teaching foreign language grammar. Pazhuhesh-e ZabanhaYe Khareji, 49, 141-164.

Nurudin. (2007). Dasar-dasar Penulisan. UGM Press.

Rahmasari, E., \& Sidabalok, D. M. (2020). Peer correction by using Google docs in descriptive text writing. Konferensi Ilmiah Pendidikan $\quad$..., 1990. https://www.proceeding.unikal.a c.id/index.php/kip/article/view/4 85

Rana, A. M. K., \& Perveen, U. (2012). Motivating Students Through Self Correction. 2(2), 1996-1999.

Sutarma, I Gusti Putu; Adnyana, I. B. A. (2014). Pembelajaran Menulis 
Kreatif berbasis Metode

Quantum Writing pada maahsiswa program studi d-4 (s1 Terapan) Manajemen bisnis pariwisata, Jurusan Pariwisata, Politeknik Negeri Bali. Aksara, 26(1), 75-85.

Tarigan, H. G. (2015). Berbicara Sebagai Suatu Keterampilan Berbahasa. Angkasa.

Tsuroyya, C. (2020). Students' Perception on Peer Correction in Academic English Writing: a Case Study in a Higher Education. Research and Innovation in Language Learning, $3(2)$, 85. https://doi.org/10.33603/rill.v3i2. 3108

Ulfah, Maria; Fuady, Amir; Wardani, N. Ek. (2013). Basastra Jurnal Pendiidkan Bahasa, Sastra Indonesia dan Pengajarannya. Journal of Chemical Information and Modeling, 53(9), 1689-1699. https://doi.org/10.1017/CBO9781 107415324.004

YastÕbaúa, G. C., YastÕbaúa, A. E. (2015). The effect of peer feedback on writing anxiety in Turkish EFL (English as a foreign language) students. Procedia Social and Behavioral Sciences, 199, $530-538$. 